\title{
Etická dimenze profese pedagoga volného času
}

\author{
Michal Kaplánek \\ Jihočeská univerzita, Teologická fakulta
}

\begin{abstract}
Abstrakt: $V$ príspěvku se nejprve vymezují význam a zdroje profesní etiky pedagogických pracovníků. Obecné principy se pak uplatňují na profesi pedagoga volného času, jak je chápána a legislativně zakotvena v České republice. Výsledkem snahy o stanovení určitých mantinelů profesní etiky také pro profesi pedagoga volného času je vznik etických kodexů některých domů dětí a mládeže. Cílem předložené studie je upozornit na specifické znaky etické dimenze profese pedagoga volného času a hledat odpověd' na otázku, zda můžeme existující etické kodexy domů dětí a mládeže považovat za vhodný nástroj zvýšení etické kompetence pedagogů, kteří $v$ těchto zařízeních pracují. Autor na základě analýzy obsahu a vzniku vybraných etických kodexů dochází $\mathrm{k}$ závěru, že vytvoření těchto dokumentů samo o sobě nestačí k zvýšení senzibilizace pedagogů volného času $\mathrm{k}$ etické problematice jejich profese.
\end{abstract}

Kličová slova: etika, etický kodex, etika pedagogické profese, korporátní kultura, pedagog volného času, pomáhající profese, zájmové vzdělávání, domy dětí a mládeže

\section{Ethical Dimension of the Profession of Leisure Educator}

Abstract: The paper defines the importance and the resources of professional ethics in education. The general principles are applied to leisure educators, as they are understood and embedded in the Czech legislation. The attempts to establish professional conduct outlines also for leisure educators led to establishing codes of ethics in several leisure-time and out-of-school centers. The aim of the present study is to point out the specific features of the ethical dimension for this profession, and to attempt to answer the question whether the current codes of ethics of the mentioned centers can be considered suitable tools for enhancing the ethical competence of leisure educators they employ. Based on the analysis of both the content and the origin of these codes of ethics, the author concludes that the mere creation of these documents is not sufficient in increasing the sensibility of leisure educators towards the ethical issues within their profession.

Keywords: ethics, code of ethics, code of ethics for educators, corporate culture, leisure educator, helping professions, leisure education, out-school-centre

V souvislosti se světonázorovou pluralitou, kterou můžeme považovat od šedesátých let 20. století za globální fenomén projevující se zejména v průmyslově vyspělých zemích s demokratickým politickým systémem, nelze počítat ani v české společnosti s jednoduchým konsenzem s tradičními etickými normami evropské tradice, které byly po staletí formované křest’anstvím. Podobně je v pluralitním prostředí obtížné se shodnout na poslání a cílech aktivit jakékoliv organizace či korporace. Současně se ve všech oblastech organizované činnosti (sociální služby, vzdělávání, ale i podnikání a další sféry života společnosti) stále více ukazuje potřeba rozvíjení korporátní 
32 kultury (corporate culture) jednotlivých organizací (O’Malley, 2000). Proto začaly vznikat etické kodexy, nejprve $v$ podnikatelské sféře anglosaské oblasti, později také u sociálních a pedagogických profesí. Etické kodexy jsou souborem zásad rozhodování, chování a jednání, které jsou projevem i prostředkem korporátní kultury (Putnová \& Seknička, 2007).

Cílem předložené studie je upozornit na specifické znaky etické dimenze profese pedagoga volného času a hledat odpověd' na otázku, zda mǔžeme existující etické kodexy domů dětí a mládeže považovat za vhodný nástroj zvýšení etické kompetence pedagogů, kteří v těchto zařízeních pracují.

\section{Profesní etika učitelů a vychovatelů}

Etické požadavky na pracovníky jednotlivých profesí závisí jak na obecných etických zásadách převládajících ve společnosti, tak na konkrétních úkolech, které mají pracovníci splnit, a na cílech, jež svou prací sledují. $V$ prípadě pedagogických pracovníků závisí etické požadavky, které na ně klademe, především na tom, jak chápeme smysl a cíle edukace. Zkoumat a navrhovat obecné principy a cíle edukace je úkolem filozofie výchovy.

Pokud bychom přijali Brezinkovu tezi, podle níž je filozofie výchovy normativní disciplínou, můžeme uvažovat nejen o normativní filozofii cílů výchovy, ale i o normativní filozofii prostředků výchovy. Ta by podle Brezinky (2001) měla být obsahem normativní etiky pro vychovatele. Brezinkův pohled na etiku jako součást pedagogické profese dále interpretuje slovenská autorka Kudláčová, která rozlišuje psychologický a etický rozměr osobnosti učitele, přičemž etický rozměr je postaven na etickém kritériu a je určen etickými principy, normami a etickým kodexem (Kudláčová, 2002).

\subsection{Filozofická východiska profesní etiky učitelů a vychovatelů}

V České republice cíle vzdělávání v různých typech škol vymezuje stát prostřednictvím rámcových vzdělávacích programů. Tyto cíle ovšem nejsou stanovovány na základě politické libovůle, ale vznikají v odborných grémiích ${ }^{1}$ a jejich formulace závisí na aktuálním odborném diskurzu nebo, přesněji řečeno, na převládajícím pojetí pedagogiky, a tedy i na převládající filozofii výchovy. Současné chápání smyslu výchovy a vzdělávání v rámci školského systému České republiky je výsledkem vývoje pedagogiky $\vee$ posledních dvou staletích, zejména $v$ anglosaské oblasti. Tento vývoj vedl $k$ tomu, že se pedagogika ve většině zemí proměnila $z$ vědy humanitní, pracující na základě filozofických metod, na vědu sociální, jejíž podstatou je empirický výzkum edukační reality. 0 této změně se zmiňuje např. Skalková (2004), když mluví o osvobození pedagogiky od jiných disciplín.

1 Rámcové vzdělávací programy se připravují a upravují ve spolupráci s Národním ústavem pro vzdělávání. 
Následkem tohoto vývoje můžeme v současné české pedagogice vnímat dva zásadně odlišné pohledy na pedagogiku, které ovlivňují priority při stanovení cílů edukačního procesu, a tedy i požadavků na pedagoga. Přitom se však zdá, že na většině vědeckých pracovišt' převládá pojetí pedagogiky jako vědy sociální a převážně explorativní. Strouhal dokonce tvrdí:

Rétorická figura praktičnosti se zdá ovládat celý pedagogický svět. Brojí se proti ryze teoretickému, od praxe odtrženému formálnímu či knižnímu vzdělání, proti vědění, jež nelze operacionalizovat, proti společensky neuplatnitelnému vzdělání... Na první pohled je zřejmé, že disjunkce, jež stojí v pozadí uvedených proklamací, nemůže být spjata s jiným než vulgárním, upadlým pojetím teorie. Jedná se tu o představu teorie jako ideologie, jež člověka uzavírá do sebe sama. (Strouhal, 2013, s. 68)

Domníváme se, že jsme v naší zemi kvưli přerušené kontinuitě humanitních věd (1948-1989) pozapomněli, že i myšlenkové pochody, filozofické teze a jejich argumentace mají svoje zákonitosti, které podléhají obdobně přísným argumentačním pravidlům, jaké předpokládáme u empirických věd. To v nás ještě zvyšuje - pro současnou dobu typickou - nedůvěru vưči teoriím, které nelze bezprostředně empiricky ověřit a prakticky využít.

Pokud uvažujeme o etické dimenzi pedagogických profesí, nestačí pouze zkoumat lidské jednání a jeho sociální a psychologické dopady. Neobejdeme se bez hledání a aktualizace etických kritérií lidského jednání. V tom případě se obyčejně opíráme o dosavadní (tradiční) mravní normy a hledáme hermeneutický klíč k pochopení jejich podstaty a následně k jejich aktualizaci. Takový postup je od starověku typický pro filozofické dotazování, které utvářelo $v$ antice tzv. bios theoretikos. ${ }^{2} \mathrm{~K}$ potřebě tohoto přístupu se odvolávají také filozofové a sociologové 20. století. Byly to často zcela rozdílné osobnosti - např́klad křest’anský filozof Josef Pieper a sociolog náboženství Thomas Luckmann -, které nezávisle na sobě plédovaly pro Stehenbleiben und Nachdenken, tedy pro potřebu zastavit se a přemýšlet, a tím navazovaly na bios theoretikos starých Řeků, který byl obsahem scholé. ${ }^{3}$ Souhrnně tedy můžeme ríci, že etické požadavky na pedagogické pracovníky vycházejí z obecně přijímaných etických norem, a to v závislosti na pohledu na život a priority vzdělávání. Pohled jednotlivého pedagoga na život i jeho osobní priority sledované v edukačním procesu jsou ovlivněny pojetím pedagogiky v odborné veřejnosti a jeho vlastní reflexí.

Téma bios theoretikos rozpracovává H. Arendtová v knize Vita activa (2009).

Výraz scholé se ve starém Řecku užíval jako opozitum k práci nutné k přežití (ascholia). Tento pojem označoval všechny činnosti (ale i nečinnost), při nichž se člověk věnoval tomu, co je charakteristické pro člověka a jeho společenský život - lásku, zábavu, poezii, hudbu, ale i kontemplaci, filozofování a vzdělávání vůbec. Jazykové ekvivalenty tohoto slova (např. leisure, loisir, Muße) se dosud použivají k označení činnosti/nečinnosti ve volném čase. V některých jazycích moderní výraz volný čas zcela nahrazují (např. v angličtině). 


\subsection{Etické požadavky na pedagogické pracovníky - vývoj a specifika v České republice}

Staré latinské přísloví i novodobá pedagogická zkušenost shodně svědčí: verba movent - exempla trahunt. ${ }^{4}$ Proto jsou obecná očekávání na charakterové kvality učitele a vychovatele stále relativně vysoká. Při přednáškách a rozhovorech se studenty pedagogiky se někdy mluví o ideálním pedagogovi. Jelikož nejsme zvyklí srovnávat se s ideálem, vnímá současná mladá generace zdůrazňování pozitivních vzorů spíše jako moralizování, což ovšem neznamená, že mladí lidé takové vzory nevyhledávají.

Pro učitelské povolání a pro pedagogické profese vůbec je z tohoto hlediska fatální spíše nízký sociální status pedagoga. Před sto, ale ještě i před padesáti lety byla společenská prestiž učitele vysoká, přestože učitelé nikdy neměli velký plat a většinou byli poplatní právě vládnoucímu režimu. Společenská prestiž byla pro učitele a učitelky současně závazkem, podobně jako je tomu dnes třeba u lékařù. Vzhledem k tomu, že škola byla nástrojem ideologie (a to nejen v době totality), byli adepti učitelství také vždy vedeni k tomu, aby si všímali chování žáků a snažili se je ovlivňovat. Po odstranění ideologie z našich škol nastalo jakési ideologické vakuum. Pluralitní demokracie v době postmoderní nejistoty totiž neumožňuje nahradit jednoznačné požadavky a „pravdy“ nějakého světonázorového postoje jiným jednoznačným postojem. Proto není velkou nadsázkou, pokud tvrdíme, že naše škola je často bezduchá (Kaplánek, 2010).

Jistě je namístě, že školy a školská zařízení zřizované státem, kraji či obcemi jsou světonázorově neutrální. Světonázorová neutralita znamená, že v těchto školách nesmí být zvýhodňován jeden světový názor či náboženství na úkor názorů ostatních. Světonázorová neutralita se ovšem nedá ztotožňovat s hodnotovou neutralitou. Svoboda svědomí a právo rodičů na výchovu dětí podle vlastních představ a ideálů neznamenají, že by se škola neměla starat o hodnotovou výchovu. Jestliže učitelé a vychovatelé z obavy před střety s rodiči rezignují na mravní výchovu žáků, přenechávají iniciativu $v$ této oblasti pouze informálnímu učení, což samo o sobě není chybou. Pokud se ovšem nejvlivnější sférou informálního učení stane komerčně zprostředkovaná zábava, nemůžeme se divit negativním důsledkům. Pokud nebude mít škola svou tvář, svého „ducha“, bude základním formačním prvkem skrytá ideologie výkonu, trhu a reklamy.

Mravní normy, které společnost považuje za závazné, vycházejí ze tří zdrojů. První zdroj lze označit jako tradice. Jedná se o komplex zásad obsažených v mravních kodexech jednotlivých kultur, náboženství a národů. Tradice je většinou dlouhodobého charakteru a její vývoj je tak pomalý, že se zdá, jako by zprostředkovávala neměnné zásady. Druhým zdrojem je veřejné mínění, které se sice v praxi opírá o tradiční hodnoty, ale přizpůsobuje je dobovým trendům. Určitý výsek z těchto norem je kodifikován v legislativě, která vytváří mantinely pro fungování společnosti, a tak se stává třetím základním zdrojem mravních norem (Kaplánek, 2010).

4 Slova hýbají - príklady táhnou. 
Etické požadavky na pedagogické pracovníky můžeme vymezit ve třech rovinách. Nejobecnější rovinou je profesní etika týkající se všech zaměstnání. Jsou to pravidla vztahů mezi zaměstnanci, mezi nadřizenými a podřízenými, muži a ženami, práva a povinnosti zaměstnanců, které nelze do detailu vyjádřit legislativně či smluvně. Druhou rovinou je profesní etika pomáhajících profesí. Jedná se o autoregulaci postojů, jednání a chování v těch povoláních, jejichž úkolem je pomáhat lidem, at' už v obtížných životních situacích (sociální práce), nebo i v jejich osobnostním rozvoji a v jejich socializaci (pedagogika). Třetí rovinou je profesní etika pedagogických pracovníků, která obsahuje pravidla charakteristická pro pedagogické profese. Zvláštním segmentem této profesní etiky je etika neučitelských pedagogických profesí, mezi něž patří také profese pedagoga volného času.

Chceme-li postupovat dále $v$ úvahách podle tohoto schématu, je třeba zkoumat, zda či do jaké míry můžeme označit povolání učitele, vychovatele, asistenta pedagoga nebo pedagoga volného času jako pomáhající profese. Široké pojetí pomáhajících profesí uvádí Géringová, s odkazem na německého psychologa Wolfganga Schmidbauera $(2000,2008)$ :

Termín pomáhající profese definuje skupinu povolání, která jsou založená na profesní pomoci druhým lidem. Patř́i mezi ně například zdravotnické profese, pedagogické profese, profese zaměřené na sociální pomoc a dále také duchovní, psychologové, terapeuti. Tyto profese mají některé společné rysy, které je odlišují od ostatních povolání. (Géringová, 2011, s. 21)

Ačkoli se $v$ uvedené definici pedagogické profese jednoznačně zařazují mezi profese pomáhající, v kontextu celkového pojetí pomáhajících profesí, jak je představuje Géringová, objevíme, že některé (samozřejmě přijímané) rysy pomáhajících profesí se nedají aplikovat univerzálně na všechny pedagogické profese. Autorka např́klad často užívá pojem klient, který se hodí na smluvní vztah (i mezi pomocníkem a pomáhajícím), nikoli však na vztah vychovatele a vychovávaného. V úvodní kapitole se zaměřuje na altruismus jako motiv pomáhání, což lze velmi těžko aplikovat napřiklad na povolání lektora jazykové školy. Pokud bychom tedy označili - ve smyslu křest’anské tradice - altruistický motiv jako jeden z významných rysů pomáhajících profesí, můžeme mezi pomáhající pracovníky zařadit učitele a vychovatele, kteří vnímají svou práci nejen jako povolání, nýbrž jako poslání. V této souvislosti je třeba konstatovat, že některé pedagogické profese nelze dobře vykonávat, pokud nejsou samotnými pedagogy vnímány jako profese pomáhající. Mezi tyto profese patří tedy i pedagog volného času, pokud sám sebe považuje nejen za instruktora nebo trenéra, ale také za vychovatele. 


\subsection{Srovnání etických kodexů pro učitele $v$ různých zemích Evropy}

Při Radě Evropy funguje panel ETINED (Platform on Ethics, Transparency and Integrity in Education), který zveřejnil v roce 2017 výzkum etických kodexů pro učitele provedený v 11 z celkem 50 zemí, které ratifikovaly Evropskou kulturní konvenci (Golubeva \& Kaninš, 2017). Jedná se o země, v nichž existuje bud' národní etický kodex pro učitele, anebo povinnost škol zavést vlastní etické kodexy. Vzhledem k tomu, že v České republice zatím nebyl národní etický kodex pro učitele přijat a vlastní kodexy mají pouze některé školy, nebyla Česká republika do tohoto výzkumu zahrnuta.

Pro účely naší reflexe jsou významná témata, jejichž výskyt, resp. absenci výzkumníci sledovali. Tato témata nám mohou napovědět, jaký je předpokládaný hodnotový základ pedagogických profesí v evropském kulturním okruhu. Jsou to následující témata: 5

- integrita (trvalý soulad slov, chování a jednání učitele);

- důstojnost (uvědomování si hodnoty vlastní osoby i ostatních osob);

- pravdivost (sdělované informace odpovídají skutečnosti);

- transparence (vlastní úmysly jsou zřejmé, bez nebezpečí manipulace);

- respekt vưči druhému (úcta k druhému člověku bez ohledu na jeho postavení);

- důvěra (schopnost důvěřvat a vzbuzovat důvěru);

- odpovědnost (přijetí odpovědnosti za vlastní jednání);

- spravedlnost (měřit každému „stejným metrem“);

- rovnoprávnost (být spravedlivý bez rozdílu pohlaví, sociálního postavení atd.);

- demokratické rízení (zapojení do spolurozhodování - participace);

- kvalitní vzdělávání (vzdělávání na potřebné úrovni);

- osobní a systémové zdokonalování (péče o vlastní růst i o vylepšování školy).

Výsledky ve sledovaných zemích se velmi lišily. Pouze $v$ jednom regionu (Katalánsko) byla $v$ regionálním etickém kodexu zohledněna všechna uvedená témata. U řady zemí jsou uvedeny př́klady dobré praxe (co se při zavádění etického kodexu osvědčilo), $v$ některých př́padech jsou také explicitně označeny překážky $v$ implementaci. Jednotlivé body, které se osvědčily, i ty, které se nadále jeví jako „výzvy“ (problémy), jsou popsány podrobněji v předposlední kapitole zprávy, která je zakončena doporučeními, po nichž následuje už jenom závěrečné shrnutí.

\section{Profese pedagoga volného času}

Profese pedagoga volného času byla v České republice poprvé legislativně vymezena v roce 2004, a to zákonem č. 563/2004 Sb., o pedagogických pracovnících, § 17. Tento paragraf vznikl patrně z potřeby vytvořit zvláštní kategorii pedagogických pracovníků s minimálním požadovaným vzděláním, kteří by mohli vést zájmové útvary

5 Vzhledem $\mathrm{k}$ tomu, že se jedná o obecné pojmy, navíc přeložené z angličtiny, doplňujeme je v tomto textu vysvětlivkami v závorkách. 
ve školských zařizeních pro zájmové vzdělávání. Tato potřeba souvisela s jedinečným vývojem mimoškolní pedagogiky v Československu po roce 1948. Zatímco v západních zemích se mimoškolní aktivita dětí realizovala a realizuje většinou bud' $v$ př́mé návaznosti na školu, anebo $z$ velké části $v$ rámci neziskových organizací, spolků, církevních institucí nebo komerčních zařízení, v socialistickém Československu byl převzat sovětský model zavedený začátkem dvacátých let - byla vytvořena jednotná organizace pro mládež i pro děti (Československý svaz mládeže, Pionýrská organizace ČSM, posléze Pionýrská organizace SSM) a vedle toho byl dán pokyn k zakládání pionýrských domů, pozdějších domů pionýrů a mládeže (DPM).

Ačkoli v padesátých letech byly DPM do značné míry závislé na místní škole a na ideologii vládnoucí Komunistické strany Československa (KSČ), během šedesátých let se sít' DPM značně osamostatnila a $v$ jednotlivých domech programově převládla zájmová činnost ve formě kroužků, souborů a oddílů. Po politickém uvolnění v roce 1968, kdy se krátkou dobu užíval název dưm dětí a mládeže, se sice v době tzv. normalizace znovu zdůrazňovaly ideologické úkoly DPM, avšak pouze formálně, podobně jako $v$ celé tehdejší československé společnosti. Ve skutečnosti došlo ke kvantitativnímu i kvalitativnímu rozvoji sítě DPM, především díky tomu, že tato zařízení byla státem financována a jejich provoz závisel z velké části na dobrovolnících-nadšencích, kteři vedli jednotlivé zájmové útvary (Dudová \& Šindelírová, 2012).

\subsection{Zájmové vzdělávání - postsocialistické specifikum}

Už sousloví „zájmový kroužek“ či „zájmový útvar“ jsou socialistické neologismy. V cizích jazycích těžko hledáme ekvivalent k přídavnému jménu „zájmový“. Pojem „zájmové vzdělávání“ totiž vychází z toho, že se dítě chce věnovat některým činnostem, které zná ze školy, do větší hloubky, dobrovolně, ve svém volném čase. Jestliže se to děje v nějaké vzdělávací instituci, označuje se toto vzdělávání jako neformální vzdělávání ( $z$ franc. éducation non-formelle). ${ }^{6}$

Po politických změnách $v$ roce 1989 se nějakou dobu zdálo, že dojde $k$ zrušení bývalých DPM, přejmenovaných opět na domy dětí a mládeže (DDM). Vzhledem $\mathrm{k}$ velkému rozsahu a společenskému významu těchto institucí a díky lobbistické práci některých odborníků, mezi nimiž hrál významnou roli Břetislav Hofbauer, ke zrušení DDM nedošlo; tyto se staly většinou př́spěvkovými organizacemi, které žijí jak z poplatků účastníků, tak především z dotací resortu školství.

Jak již bylo zmíněno, činnost DDM závisí na práci dobrovolníků. Ti ovšem nemají status dobrovolníka, nýbrž pedagogického pracovníka. $K$ vedení zájmového útvaru v DDM (většinou v rámci dohody o provedení práce) tedy potřebují nějaké minimální pedagogické vzdělání. Ačkoli se koncem devadesátých let uvažovalo o schválení „zákona o mládeži“ (obdoby německého zákona Kinder- und Jugendhilfegesetz), který by upravoval podmínky práce s dětmi a mládeží, došlo nakonec ke změně pouze v souvislosti s vydáním nového školského zákona č. 561/2004 Sb. Vznikl zákon o pe-

6 K definici tohoto pojmu např. Camier-Théron (2013). 
38 dagogických pracovnících, $v$ němž jsou vymezeny jednotlivé pedagogické profese; mezi nimi také „nová“ profese pedagoga volného času.

Do roku 2012 se nerozlišovaly kvalifikační předpoklady na vedoucího zájmových útvarů, který nebyl kmenovým zaměstnancem školského zařízení, od nutně vyšších kvalifikačních nároků na zaměstnance, kteří v zařízení pracují jako pedagogové volného času na plný nebo částečný úvazek. Teprve $v$ roce 2012 se podařilo prosadit do zákona o pedagogických pracovnících rozlišení mezi „pedagogem volného času, který vykonává komplexní př́mou pedagogickou činnost v zájmovém vzděláváni“", a pedagogem, který vykonává „dílčí prímou pedagogickou činnost“. Pro vykonávání obou pracovních zařazení stačí jakékoli terciární či sekundární pedagogické vzdělání, případně pouze kurz akreditovaný v systému dalšího vzdělávání pedagogických pracovníků (DVPP). Rozdíl v kvalifikačních požadavcích pro komplexní a dílčí pedagogickou činnost spočivá pouze $v$ tom, že minimální kvalifikační požadavky na komplexní př́mou pedagogickou činnost v zájmovém vzdělávání zahrnují maturitu a kurz pedagogiky v rozsahu 120 hodin, zatímco pro dílčí prímou pedagogickou činnost stačí výuční list a kurz v rozsahu 40 hodin (zákon č. 563/2004Sb.). Z hlediska kvality vzdělávání pedagogů pro resort zájmového vzdělávání považujeme za dílčí úspěch, že k tomuto rozlišení vůbec došlo. Z přijetí novely § 17 zák. č. 563/2004 Sb. totiž vyplývá, že zákonodárce uznává rozdíl v pedagogické odpovědnosti mezi pedagogickými pracovníky, kteří odpovídají za tvorbu školního vzdělávacího programu a za úroveň edukačního procesu ve školském zařízení, od vedoucích zájmových útvarů, kteři věnují svůj volný čas tomu, že zprostředkovávají dětem dílčí kompetence v některé vzdělávací oblasti (společenskovědní, sportovní, ekologické, umělecké, technické). Bohužel má tato úprava dva zásadní nedostatky: požadované minimální vzdělání pedagoga volného času, který vykonává komplexní prímou pedagogickou činnost v zájmovém vzdělávání, je nesrovnatelně nižší, než jsou požadavky na učitele. Zatímco učitel základní a střední školy musí mít vysokoškolské vzdělání v magisterském stupni, profesionálnímu pedagogovi volného času stačí k výkonu jeho povolání pouze maturita a kurz zakončený závěrečnou zkouškou, aniž by musel prokazovat znalosti jednotlivých pedagogických a psychologických disciplín v dílčích zkouškách. Druhým nedostatkem je, že záměr zákonodárce rozlišit mezi komplexní a dílčí pedagogickou činností není implementován do příslušného prováděcího předpisu, čímž je vyhláška č. $317 / 2005 \mathrm{Sb}$.

Př́loha č. $5 \mathrm{k}$ této vyhlášce obsahuje poměrně přesné, byt' obecné a vzhledem ke vzdělání nediferencované, vymezení činnosti pedagoga volného času. Pedagog volného času, který získal minimální vzdělání pro tuto profesi, může vykonávat všechny následující činnosti, přičemž míra náročnosti a odpovědnosti není spojena s žádným dalším kvalifikačním požadavkem a řídí se pouze náplní práce konkrétního pracovníka. Jedná se o tyto činnosti:

- výchovná a vzdělávací činnost zaměřená na oblast volného času;

- komplexní pedagogická, primárně diagnostická a preventivní činnost v oblasti volného času včetně prevence sociálně patologických jevů a prevence bezpečnosti a ochrany zdraví; 
- tvorba programů, poskytování metodické a konzultační činnosti a specializované odborné pomoci subjektům působícím v oblasti zájmového vzdělávání a volného času;

- zajišt'ování péče o talenty;

- organizace soutěží, přehlídek, soustředění, pobytů a táborové činnosti;

- tvorba obecných celostátních nebo krajských forem a metod ve výchově a vzdèlávání v oblasti volného času;

- komplexní metodická a koordinační činnost v oblasti výchovy a vzdělávání a dalšího vzdělávání pracovníků.

\section{2 Čtyři pojetí profese pedagoga volného času}

Vycházíme-li tedy z vymezení profese pedagoga volného času, jak ji zná současná česká legislativa, lze zjednodušeně ř́ci, že se na pedagoga volného času v plném rozsahu vztahují požadavky profesní etiky společné pro všechny pedagogické pracovníky (učitele, vychovatele, asistenty pedagoga). Výchovné úkoly pedagoga volného času jsou totiž z hlediska legislativních nároků srovnatelné s úkoly učitelů a vychovatelů.

Při úvahách o etické dimenzi profese musíme ovšem uvážit, že legislativní vymezení jakéhokoli povolání určuje pouze základní rámec jeho výkonu. Reálná náplň práce a pojetí odpovědnosti závisejí na tom, co považují jednotliví zaměstnanci a jejich nadřízení za podstatné a co naopak odsouvají jako okrajové.

Z hlediska odborného př́stupu a priorit můžeme rozeznat v českém prostředí čtyři pojetí práce pedagoga volného času, když nebudeme uvažovat o nepedagogických profesích zaměřených na volný čas (oblast cestovního ruchu, zážitkově zaměřené aktivity bez pedagogického záměru atp.).

První pojetí je charakteristické pro vedoucí zájmových útvarů, kteří se orientují přednostně na předání konkrétních dovedností. Jsou to vedoucí, kteří chápou svou úlohu spíše jako roli trenéra, instruktora či lektora. Tato role je namístě, pokud mluvíme o vzdělávacích kurzech pro dospělé, př́padně o trénování nebo výcviku dospělých, at' už za účelem rekvalifikace, anebo sledování vlastních zájmů - koníčků. Pokud by ale pedagog volného času pracující s dětmi a mládeží spatřoval svůj úkol pouze $v$ předávání vědomostí a dovedností, opomenul by téměř celou výchovnou dimenzi své profese, byl by v nejlepším případě „didaktickým technikem“, tedy člověkem, který zná způsoby, jak nejlépe předat informace a zprostředkovat dovednosti. Takový př́stup, $v$ němž nejde $v$ první řadě o výchovu, ale spí̌e o předávání znalostí a dovedností, se očekává od instruktorů a lektorů celoživotního vzdělávání, které si platíme (jako „klienti“), aby nám předali znalosti a dovednosti jako určitý produkt. To ovšem neznamená, že pedagog tohoto typu nemusí mít lidský př́stup. Zkušenosti totiž učí, že právě př́ijemná a přátelská atmosféra zvyšuje efektivitu učení.

Protikladem instruktora je vychovatel v tradičním pojetí, který chápe svoje povolání jako pomáhající profesi. Je to paidagogos, tedy průvodce člověka $v$ počátečních etapách jeho životní cesty. Jeho posláním je paideia, tedy „vytržení z všedního dne“, „povznesení z všednodenní zaneprázdněnosti k reflexi této mravenčí připoutanosti“ (Palouš, 1987, s. 21). 
Pokud chápeme jako centrální úkol pedagoga volného času zprostředkování odborných kompetencí v rámci zájmového vzdělávání, jen velmi těžko můžeme u této profese objevit tradiční vychovatelský étos. Cestou k hlubšímu smyslu profese pedagogiky volného času může být Opaschowského pojetí Freizeitpädagogik, které se začalo rozvíjet jako pedagogická odpověd' na propast mezi prací a volným časem, jež vznikla rozporem mezi nudou a monotónností práce a zábavou ve volném čase, kterou dělníci s nízkou kvalifikací začali kompenzovat svou nespokojenost. Tento problém, na nějž poprvé upozornil Jürgen Habermas (1958), je v nové formě stále aktuální: řada lidí si vydělává prací, která je neuspokojuje, a tak potřebují realizovat své potřeby a touhy ve volném čase. Aby lidé neztratili svobodu svého volného času, je třeba jim pomáhat $\mathrm{k}$ dosažení volnočasové kompetence, $\mathrm{tj}$. ke schopnosti svobodně si vybírat z volnočasových nabídek a být rezistentní vưči tlaku konzumu a reklamy (Küchenhoff, 1970).

Další pojetí profese pedagoga volného času nabízí koncepce animace, která předpokládá u každého člověka skrytý potenciál schopností, který animátor pomáhá objevit, realizovat a rozvinout. Tato důvěra $v$ „dobré jádro“ $v$ každém člověku umožňuje motivovat i lidi, kteří si nedůvěřují anebo vůbec o svých schopnostech nevědí. Dle Marka Smitha se v animaci odráží jeden ze tř́ pohledů na pedagogiku, které mají svůj původ již ve starověku: educatio - formatio - animatio. Zatímco edukace chce „vyvádět člověka z nevědomosti“ do uvědomění si skutečnosti, formace chce předávat kompetence potřebné pro život, animace probouzí to cenné, co člověk v sobě nese, ač si to někdy ani neuvědomuje (Kaplánek, 2013a).

Poslední z pojetí pedagogiky volného času, které můžeme $v$ českém prostředí identifikovat, je pedagogika citlivá k sociálním vztahům a problémům mladých lidí. Je to pedagogika zaměřená na pomoc mladým lidem při jejich socializaci, zejména těm, kteři mají socializační problémy. Jedná se tedy o sociálně pedagogickou praxi. Př́kladem realizace sociální pedagogiky může být činnost kongregace salesiánů Dona Boska a některých sociálních pracovníků nízkoprahových zařízení pro děti a mládež (NZDM), kteří vnímají jako svůj úkol nejen pomoc mladým lidem v jejich aktuálních problémech, ale také $v$ jejich hledání životní vize, životního nasměrování.

Pokud bychom chtěli rozlišit etické nároky na pedagogy volného času podle uvedených koncepcí, můžeme bez rozpaků říci, že jak typ pedagoga volného času vychovatele, tak i pedagoga animátora a sociálního pedagoga můžeme zařadit mezi pomáhající profese.

\section{3 Řešení požadavků na pedagoga volného času zavedením etického kodexu}

Z uvedených pojetí pedagogiky jako takové i z různých přistupů k profesi pedagoga volného času můžeme vyvodit, že pokud chápeme pedagogickou profesi jako životní poslání, vnímáme silně mravní odpovědnost nejen za vlastní jednání, ale také za príklad, pozitivní či negativní, který dáváme dětem. Význam tohoto príkladu závisí na autoritě spojené s profesí. Ačkoli formální autorita učitelů a vychovatelů v po- 
sledních desetiletích v našem kulturním okruhu klesla, hrají pedagogové i nyní roli vzoru či modelu sociálního jednání.

Jak jsme zmínili již v úvodu této stati, tradiční mravní zásady přestaly být samozřejmostí, která by byla podrobena sociální kontrole. Pluralita hodnotových systémů ve společnosti způsobila, že si každá korporace musí vytvářet a „hlídat“ svoje klíčové hodnoty sama, samožrejmě ve spolupráci s dalšími stejně orientovanými institucemi. Potřeba jasně formulovaného poslání a sdílených hodnot jednotlivých institucí a organizací - od komerčních až po charitativní - vedla k vzniku a rozvoji etických kodexů.

V současnosti také v České republice některé školy a školská zařízení zveřejnily své etické kodexy. Protože je tato studie zaměřena na profesi pedagoga volného času, pokusili jsme se analyzovat vybrané etické kodexy domů dětí a mládeže. Při systematickém vyhledávání etických kodexů přes internetové stránky zařizení ve Sdružení pracovníků DDM v ČR jsme na webech 75 zařízení z Prahy a dalších čtyř krajů našli pouze jeden etický kodex. V další vlně jsme proto vyhledávali s využitím klíčových slov, logických operátorů a webového vyhledávače. Tímto postupem jsme získali sedm etických kodexů pedagogických pracovníků DDM různých zřizovatelů (kraj, statutární město, církevní instituce).

Použili jsme metodu kvalitativní obsahové analýzy. Sběr i analýza dat probíhaly současně; podle výsledků průběžné analýzy jsme rozhodovali o potřebě dalších výzkumných dat. Naše domněnky a závěry jsme průběžně přezkoumávali. Stěžejní bylo stanovit znaky, které se měly stát zásadní pro následnou analýzu. Tyto znaky jsme pracovně zahrnuli do několika kategorií: první odrážela nároky obecně profesní či manažerské, druhá zahrnovala spíše znaky vypovídající o přistupu ke klientům či účastníkům aktivit a třetí se týkala osobnosti pedagoga volného času.

Na základě srovnání struktury a obsahu etických kodexů a jejich znaků jsme byli schopni identifikovat dva základní typy těchto dokumentů, které rovněž svědčí o dvou přistupech k profesní etice pedagoga volného času.

Prvním (A) je přístup, který bychom mohli označit jako manažersko-profesní. $V$ tomto případě nebyl ve středu zájmu (pouze) vztah pedagoga (volného času) k dětem, ale spíše postoje a chování zaměstnanců zařízení vưči kolegům, vedoucím pracovníkům, dětem a ostatním účastníkům. Motiv vzniku takového dokumentu spočival spíše v potřebě upravit zaměstnanecké vztahy či dát jasná pravidla (standardy) jednání, a tak usnadnit spolupráci uvnitř organizace, ale i navenek - vưči dětem a ostatní veřejnosti. Druhý přístup (B) se liší tím, že etické kodexy se v těchto střediscích zaměřují explicitně (a vlastně výhradně) na pedagogy volného času. Obsahově jsou si podobné a lze říci, že jsou výčtem požadavků na osobnost pedagoga volného času.

Jako př́klady prvního přístupu (A) nám zde poslouží etické kodexy tří domů dětí a mládeže. ${ }^{7}$ Etický kodex prvního z těchto zařízení vznikl dle sdělení jeho ředitelky

7 Údaje o konkrétních zařízeních a odkazy na jejich webové stránky neuvádíme, abychom dostáli požadavkům důvěrnosti a anonymity při pedagogickém výzkumu (srov. Průcha \& Švaříček, 2009). Všechny informace nad rámec veřejně dostupných zdrojů jsou uloženy v archivu autora. 
42 v roce 2010 na základě tehdy aktuální potřeby „překonat personální krizi“. ${ }^{8}$ Po stránce obsahové byl inspirací při vzniku tohoto etického kodexu etický kodex zaměstnanců př́slušného krajského úřadu. Vzhledem $\mathrm{k}$ okolnostem vzniku je pochopitelné, že se tento kodex zaměřuje především na vztahy mezi kolegy a k zaměstnavateli a poté na osobnostní vlastnosti zaměstnanců (není rozlišeno, zda pedagogů, nebo nepedagogických pracovníků). Postoje specifické pro pedagoga volného času jsou spíše na okraji zájmu dokumentu. Odráží se pouze v Obecných zásadách (čl. I) a v Etických zásadách odbornosti a povolání (čl. III). Z hlediska odpovědnosti je v dokumentu zdůrazněna odpovědnost vůči veřejnosti. Vzhledem $\mathrm{k}$ tomu, že dokument neobsahuje mnoho konkrétních požadavků specifických pro pedagoga volného času, nelze z něho přesně vyčíst, jaké pojetí této profese přijali tvưrci dokumentu.

Druhý analyzovaný dokument profesně-manažerského př́stupu upravuje činnost domu dětí a mládeže registrovaného jako školská právnická osoba podle $\$ 8$ odst. 6 zák. č. 561/2004 Sb. Vznikl v roce 2006 a v nedávné době byl aktualizován. Impulzem k vzniku dokumentu byly $v$ tomto př́padě právě vznikající etické kodexy sociálních služeb, zejména Etický kodex České asociace streetwork (Česká asociace streetwork, 2017). Vzhledem $\mathrm{k}$ tomu, že některá zařizení tohoto typu provozují vedle hlavní činnosti domu dětí a mládeže také nízkoprahové zařízení pro děti a mládež (jako vedlejší činnost), je nasnadě, že etická pravidla jsou převzata z etických zásad kodexů užívaných v sociální oblasti. Jsou však adaptována na specifickou situaci těchto zařizení, v nichž se realizují nejen přistupy sociální práce, nýbrž také přistupy sociální pedagogiky. ${ }^{9}$ Struktura dokumentu je podobná předcházejícímu dokumentu, přesto je zde mnohem větší důraz kladen na vztah pracovníků DDM vưči dětem. Ačkoli se autoři inspirovali u etických kodexů sociálních služeb, používají pojem „děti“, a nikoli „klienti“. Z obsahu i kontextu dokumentu můžeme konstatovat, že $v$ tomto zařízení vnímají profesi pedagoga volného času v jeho sociálním rozměru, tedy jako sociálního pedagoga.

Třetím príkladem přístupu (A) je etický kodex DDM zřízeného statutárním městem. Tento dokument se svou strukturou liší od předešlých dvou př́kladů, ačkoliv i on se explicitně věnuje hlavně zaměstnaneckým vztahům a profesní etice $v$ obecném slova smyslu. Přestože se $v$ textu objevuje věta: Ke svému povolání přistupujeme jako $k$ poslání, nelze na základě této jediné věty usuzovat na nějaký hlubší pohled tvůrců kodexu na profesi pedagoga volného času. Z kontextu vyplývá, že jde o to, aby zařizení fungovalo a mělo na veřejnosti dobré jméno. $Z$ toho můžeme usuzovat, že v tomto zařízení převládá pojetí pedagoga volného času jako lektora či instruktora.

Od manažersky zacílených etických kodexů se liší etické kodexy obsahující výčet očekávaných vlastností pedagogů volného času (B). Mezi zkoumanými dokumenty jsme našli dva príklady tohoto prístupu. $V$ obou případech se jedná o DDM v malém městě. Obsahově jsou oba kodexy prakticky totožné, rozdíly jsou marginální. Lze předpokládat, že tyto etické kodexy byly nepřímo ovlivněny jak etickými kodexy

8 E-mailové sdělení autorovi statě 30. října 2018.

9 Ke vztahu mezi sociální prací a sociální pedagogikou např. Kaplánek (2013b). 
pro pracovníky v sociálních službách, tak Code of Ethics for Educators zveřejněným $\checkmark$ USA (Association of American Educators, 2009). Na vliv etických kodexů pracovníků sociálních služeb usuzujeme z nereflektovaného používání výrazů „klient“. Některé požadavky, např. „,nezneuživá svého postavení“, mohly jen těžko vzniknout na základě reflexe české reality, z čehož lze usuzovat na zahraniční předlohy, na jejichž základě se v roce 2005 začalo uvažovat o vytvoření etického kodexu učitele (Sarközi, 2005).

Pokud bychom dle textů etických kodexů těchto dvou zařizení chtěli odvodit, jaké je pojetí profese pedagoga volného času u tvưrců těchto dokumentů, asi bychom zařadili obě zařízení mezi pracoviště, kde se očekává, že pedagog volného času bude vychovatelem v tradičním slova smyslu. Jenže nedostatek originality tvưrců těchto dokumentů je podnětem k pochybnosti nad tímto závěrem. Spíše se zdá, že autoři chtěli uvést něco „správného“, bez ohledu na reálnou situaci jejich zařizení. Z tohoto hlediska by bylo zajímavé zkoumat, do jaké míry se vznešené principy obsažené v etických kodexech skutečně realizují.

\section{Závěr}

Tento „výlet do krajiny etických kodexů“ nám naznačil, že tyto dokumenty jsou užitečným prostředkem ke stanovení základních pravidel jednání v různých organizacích, a tedy i ve školských zařizeních. Nemůžeme však očekávat, že se vytvořením a zavedením etických kodexů skutečně zvýší etická kompetence pedagogů. Proto musíme hledat jiné cesty senzibilizace pedagogů - včetně pedagogů volného času k etické problematice jejich profese.

Mohli bychom uvažovat o etické dimenzi cílů a metod výchovného působení ve volném čase. Mưžeme se ptát, které metody jsou eticky přijatelné a které nikoli. Můžeme uvažovat o tom, kde je hranice mezi „pedagogickým ovlivňováním“ a „manipulací“. To jsou otázky, které je třeba vnést do vzdělávání pedagogů. Pouze tehdy, když i pedagog pracující ve volnočasovém zařizení bude citlivý vưči etickým dilematům svého povolání, můžeme mluvit o zvyšování úrovně etické dimenze profese pedagoga volného času.

\section{Literatura}

Arendtová, H. (2009). Vita activa. Praha: Oikoymenh.

Association of American Educators. (2009). Code of ethics for educators. Dostupné z www .aaeteachers.org/index.php/about-us/aae-code-of-ethics

Brezinka, W. (2001). Východiska k poznání výchovy. Brno: L. Marek.

Camier-Théron, M. (2013). L'éducation non-formelle ou comment apprendre tout au long de la vie. Animafac. Dostupné z www.animafac.net/blog/l-education-non-formelle-ou -comment-apprendre-tout-au-long-de-la-vie/

Česká asociace streetwork. (2017). Etický kodex České asociace streetwork. Dostupné z www .streetwork.cz/uploads/files/attachments/5a1e8a28044d4_eticky_kodex_01-2017.pdf 
44 Dudová, A., \& Šindelířová, E. (2012). Volný čas - předmět zájmu sociologie a pedagogiky. In M. Kaplánek (Ed.), Čas volnosti - čas výchovy (s. 57-92). Praha: Portál.

Géringová, J. (2011). Pomáhající profese. Tvořivé zacházení s odvrácenou stranou. Praha: Triton.

Golubeva, M., \& Kaninš, V. (2017). Codes of conduct for teachers in Europe: A background study. Strassbourg: Council of Europe. Dostupné z https://rm.coe.int/vol-4-codes-of-conduct-for-teachers-in-europe-a-background-study/168074cc72

Kaplánek, M. (2010). Škola bez ducha je škola bezduchá? E-pedagogium, 10(2), 20-27.

Kaplánek, M. (2013a). Animace. Praha: Portál.

Kaplánek, M. (2013b). Sociální pedagogika a sociální práce. In O. Matoušek (Ed.), Encyklopedie sociální práce (s. 503-506). Praha: Portál.

Kudláčová, B. (2002). Etika a osobnost' učitel'a. Trnava: TU.

Küchenhoff, W. (1970). Freizeiterziehung. In H. Rombach (Ed.), Lexikon für Pädagogik 2 (s. 27-28). Freiburg: Herder.

O'Malley, J. (2000). How to create a winning corporate culture. Birmingham Business Journal. Dostupné z https: / /www.bizjournals.com/birmingham/stories/2000/08/14/focus6.html

Palouš, R. (1987). Čas výchovy. Roma: Křest'anská akademie.

Průcha, J., \& Švaříček, R. (2009). Etický kodex české pedagogické vědy a výzkumu. Pedagogická orientace, 19(2), 89-105.

Putnová, A., \& Seknička, P. (2007). Etické rízení ve firmě. Praha: Grada Publishing.

Sarközi, R. (2005, 21. února). Pedagogická komora a etický kodex učitele. Britské listy. Dostupné z https: / /legacy.blisty.cz/art/22108.html

Schmidbauer, W. (2000). Psychická úskalí pomáhajících profesí. Praha: Portál.

Schmidbauer, W. (2008). Syndrom pomocníka. Praha: Portál.

Skalková, J. (2004). Pedagogika a výzvy nové doby. Brno: Paido.

Strouhal, M. (2013). Teorie výchovy. K vybraným problémům a perspektivám jedné pedagogické discipliny. Praha: Grada.

Vyhláška č. 317/2005 Sb., o dalším vzdělávání pedagogických pracovníků, akreditační komisi a kariérním systému pedagogických pracovníků.

Zákon č. 561/2004 Sb., o předškolním, základním, středním, vyšším odborném a jiném vzdělávání (školský zákon).

Zákon č. 563/2004 Sb., o pedagogických pracovnících.

doc. Mgr. Michal Kaplánek, Th.D. katedra pedagogiky Teologická fakulta, Jihočeská univerzita Kněžská 8, 37009 České Budějovice kaplanek@tf.jcu.cz 